\title{
The Use of YouTube based Interactive Learning Media in Giving English Subject Material for Middle School Students
}

\author{
Tanti Tiara ${ }^{1}$, Yousef Bani Ahmad ${ }^{2}$, Abdul Kodir Al-Baekani ${ }^{3 *}$ \\ ${ }^{1}$ (Singaperbangsa University of Karawang). \\ ${ }^{3}$ (Singaperbangsa University of Karawang). \\ ${ }^{2}$ (Singaperbangsa University of Karawang). \\ * Corresponding Author. E-mail: ${ }_{\text {tantitiaraaa@gmail.com }}$
}

Receive: $13 / 05 / 2021$

Accepted: 23/08/2021

Published: 01/10/2021

\begin{abstract}
Abstrak
Tujuan penelitian adalah untuk melihat persepsi siswa kelas VIII terhadap penggunaan media pembelajaran interaktif berbasis YouTube dalam memberikan materi pelajaran bahasa Inggris. Alasan peneliti melakukan penelitian ini adalah karena para pendidik di SMP menggunakan youtube sebagai media pembelajaran yang diharapkan agar siswa dapat memahami materi yang sedang dipelajari, sehingga siswa dapat tetap mengikuti proses belajar mengajar di masa pandemi. , khususnya pada mata pelajaran bahasa Inggris. Penelitian ini menggunakan penelitian kualitatif dengan pendekatan inkuiri naratif dan analisis tematik untuk melihat respon penggunaan YouTube. Untuk mendapatkan hasil yang akurat, peneliti menggunakan kuesioner dan wawancara. Subjek penelitian ini adalah siswa kelas VIII di salah satu SMP di Karawang yang sudah terbiasa menggunakan media youtube. Berdasarkan hasil penelitian yang telah dilakukan terhadap penggunaan media interaktif berbasis YouTube untuk memberikan materi bahasa Inggris adalah 4 dari 5 siswa kelas VIII di salah satu SMP di Karawang menyukai dan senang dengan cara guru menyampaikan materi melalui video youtube di masa pandemi ini karena menjadi fokus pembelajaran dan materi menjadi mudah dipahami.
\end{abstract}

Kata Kunci: Media pembelajaran interaktif, YouTube, Mata Pelajaran Bahasa Inggris.

\begin{abstract}
The research objective is to see eight grade students' perception of the use of interactive learning media based on YouTube in giving English subject material. The reason of researcher did this research is because the educators at the junior high school use YouTube as a learning medium which is expected so that students can understand the material being studied, so that students can continue to follow the teaching and learning process during the pandemic, especially in English subjects. This study used a qualitative research with narrative inquiry approach and thematic analysis to see the response of the use of YouTube. In order to get accurate results, the researchers used questionnaire and interviews. The subjects of this study were 8th grade students in one of junior high school in Karawang who are familiar with using YouTube as a media. Based on the results of the study, that had been conducted on the use of YouTube-Based interactive media to giving English material was that 4 out of 5 eighth grade students at one of junior high school in Karawang liked and were happy with the way teachers delivered material through YouTube videos during this pandemic because they become the focus of learning and the material becomes easy to understand.
\end{abstract}

Keywords: Interactive learning media, YouTube, English Subject 


\section{INTRODUCTION}

In the Industrial Age 4.0 and the addition of the Pandemic, E-Learning has become an important foundation in the world of education. This argument is proven because E-Learning can provide students the flexibility to open and study Learning Content wherever and whenever they want (Lee et al., 2017). The development in the new normal era expects all educators to be proficient in information and technology and innovate in order to create a more interactive education in all fields. Facing the world of education which is increasingly affected in the new normal era requires educators and teaching staff to be at home only or work from home (WFH). This makes it an obligation to form interactive multimedia for lecturers to be more creative and innovative. Learning media in general is a tool for teaching and lear.ning process. Everything that can be used to generate thoughts, feelings, attention and abilities or skills of learners so that it can encourage the learning process. This limitation is quite broad and deepens the understanding of sources, environment, people and methods used for learning/training purposes (Soenarko et al., 2018). This is certainly a challenge for middle school and middle school teachers who are not young anymore, because generally they will have difficulty understanding something that is still new in their world.

However, considering the many benefits of the internet for the world of education, for example to facilitate the search for sources of English learning materials to support the success of their learning process to be able to master the internet. Guidelines for the Prevention and Control of Coronavirus Disease 2019 (COVID$19)$ is a reference for the Central Government, Provincial Governments, Regency / City Governments, health service facilities, health personnel, and all related parties in making efforts to prevent and control Coronavirus Disease (COVID-19). So that it makes teachers and students meet in a non-face to face learning. YouTube is one of the learning media in English in the form of videos and social media which are often accessed by students in seeking information. On the other hand, learning is a process of communication between students, educators and teaching materials. Many people think that the current generation quickly experiences boredom and laziness in learning. Various studies have shown that the generation known as the internet generation actually has a high learning orientation and enthusiasm. However, the difference is only on the varied way they get information.

Currently, there are various learning models that can be applied in the vocational middle school environment. One of the learning models to improve students' understanding is to utilize information technology facilities. Internet media provides various facilities that can support learning, one of which is YouTube. Youtube is considered as one of the media that has tremendous potential to improve the quality of distance learning (DeWitt et al., 2013; Kamhar and Lestari, 2019). The facilities available on Youtube should be used by teachers because this media is one of the most effective media to convey information to students.

YouTube is platform that majorly based on sharing of video which is customized uploaded by the users (Pinto, Almeida \& Gonçalves, 2013). Usually, the platform allows the users to keep track and manage a record of users that view the videos. Historically, YouTube was founded by Steve Chen, Jawed Karim and Chad Hurley in February 2005 (Graham, 2005). YouTube is currently most popular online video community where millions of people can share and watch originally-created videos. YouTube provides a forum for people to inform connect, and inspire others across the globe and acts as a major distribution 
platform for original content creators for viewer to see. YouTube is a modern mass media commonly used in this new digital age. Cheng, Liu \& Dale (2013) considered videos on the channel as entertainment-based, meanwhile some researchers categorize the platform as broadly based with potentials for education and life-long learning. Kay (2012) gave a broad review of research on video podcasts to provide a framework for an educational approach to the new media. Duncan, Yarwood-Ross \& Haigh (2013) explained the importance and relevance of video sharing sites and argued that YouTube videos were valuable to practical, education, and research. Duffy (2008) opined YouTube could also be useful in the educational process by creating a learning community where everyone has a voice and practically understand the purpose of the video. By implementing YouTube into the educational process, teachers are providing students with a learning environment in which they can thrive through having access to practical and reality of the subject content.

\section{A. Meaning of YouTube Media}

Judging from the etymology of the word media comes from the Latin medius which literally means "middle", "intermediary" or "introduction". Media is the plural form of media which literally means "intermediary", is a means of communication. As for Gerlach \& Ely in Azhar Arsyad's book (2016), that the media if understood broadly is human, material, or condition-building events, which causes students to be able to acquire knowledge, skills, or attitude.

According to Andrea Wilson (2018), YouTube media is a video sharing service that provided by Google for its users to load, watch and share video clips for free. YouTube is a form of the shift in internet technology (world wide web) from "read only web" to "read write web", which is from a situation when the internet only provides data reading resource for users to the current state of the internet provides a means for users to create and share reading resource for other users. The shift causes YouTube to be one of the most practical and effective social media easy to access, so YouTube is currently the most popular site and watched by thousands of people every day.

\section{B. YouTube as a Media in giving Material}

YouTube is a multifaceted resource that provides easily accessible videos in a variety of subject areas. As more and more study indicates significant discoveries supporting the integration of YouTube video clips in education, YouTube technology can be considered a great learning tool. As Mayer has mentioned earlier, video is very effective, especially for introductory courses, because it can facilitate difficult concepts and attract students' attention (Mayer, 2001). Besides, videos on YouTube have a time limit which makes them suitable for limited class time. Studies have also examined how YouTube can be part of a learning system to support self-learning in language learning (Hafner \& Miller, 2011). Studies show how YouTube can increase student engagement and participation in class and present learning strategies (Callow \& Zammit, 2012).

Youtube as a media has many benefits to be used during the process of teaching and learning activities. There are several experts who state the positives (benefits) of learning media. Among them, Sudjana and Rivai (2011: 2) state the benefits of media in the student learning process, namely, first, so that attention is more focused on the material when learning so that the enthusiasm for learning will increase. both teaching materials are clearer so that the objectives in teaching and learning activities can be achieved and students are able to master the material 
well. The three students do a lot of activities while studying because students do not only listen to the material given by the teacher but students have other activities such as observing, practicing something and many others. From the opinion of Sudjana and Rivai, it can be concluded that the benefit (usability) of the media in learning is that it can focus teaching and learning activities to be more effective. So that students become more enthusiastic and enthusiastic in participating in the process of learning activities, and in the end the initial learning objectives are expected to be achieved well.

\section{YouTube Media Function}

Sudjana and Rivai (2016) explained tht the purpose of the media learning, that is, students are expected to have the ability to better after going through various learning experiences accompanied by with knowledge sourced from the curriculum. Wigati (2018) explain the purpose of learning YouTube as a learning media is to create conditions and an atmosphere of learning that interesting, fun and interactive. Media learning videos YouTube can be used for interactive learning in the classroom, either for students and teachers themselves through online presentations and offline. Based on this explanation, the researcher argues that: that YouTube's media learning objectives provide students better ability to accept the material presented by the teacher so that classroom learning can be interactive and improve learning outcomes.

\section{METHODOLOGY}

The research method at this stage is by using qualitative research with narrative inquiry approach. Departing from the existing problems, this research wants to know how to see eight grade students' perceptions of the use of YouTube videos in the English subject matter given by their teacher in one of the junior high schools in Karawang, and then researcher started from give questionnaires and interviews. This research emphasizes the use of interactive learning media based on YouTube (Creswell, 2010). To collect the data, this research used instruments used questionnaires and interviews. The researcher used a closeended questionnaire adapted from Sirait (2021) and Masyitoh (2017) with the following assessments: 1 ) Strongly Disgree; 2 ) Disagree, 3) Neutral, 4) Agree, and 5) Strongly Agree. The questionnaire has three points to examine about the use of youtube videos; The experience, the comprehension, the dificulty. Besides, an open-ended interview was conducted to strengthen the result of the questionnaire. The questionnaires were given to the participants via Google Form and the interview was conducted via WhatsApp Calling application due to the Pandemic situation. After the data was collected, the researcher analyzed the data descriptively by considering the steps from Creswell (2009:183): preparing data for analysis, reading and understanding all the data, classifying the data, interpreting the data, and drawing the conclusion.

\section{RESULTS AND DISCUSSION}

\section{Results}

Based on the thematic analysis technique used to analyze, the results of this study are presented in accordance with the themes obtained from the process of coding and determining sub-themes. These themes are grouped based on the participants' perceptions of the use of YouTube as an interactive media to convey English material. And to find out the result, the researchers used data collection techniques with questionnaires and interviews. The technique was carried out on 5 participants who were eight grade students at SMPN 2 Telukjambe Timur Karawang. The questionnaire has three points to examine about the use of YouTube videos; The experience, the comprehension, the dificulty. And in the interview questions, there are $\mathbf{2 0}$ questions that the researcher 
adapts from previous researchers, the questions will be described by researcher. And based on interviews that have been conducted by researchers, it is known that 8 grade students are more focused and understand the English material that has been given by their teacher through YouTube videos.

\section{a. Participant's Experiences}

Table 1. Participant's Experiences

\begin{tabular}{|c|c|c|c|c|c|c|}
\hline $\begin{array}{l}N \\
\text { o. }\end{array}$ & $\begin{array}{l}\text { Pernyataan } \\
\text { (Statements) }\end{array}$ & $\begin{array}{l}\text { STS } \\
\text { (SD } \\
\text { ) }\end{array}$ & $\begin{array}{l}\text { TS } \\
\text { (D) }\end{array}$ & $\begin{array}{l}\text { BS } \\
\text { (N) }\end{array}$ & $S(A)$ & $\begin{array}{l}\text { ST } \\
\text { (SA) }\end{array}$ \\
\hline 1. & $\begin{array}{l}\text { Menurut saya } \\
\text { bahasa Inggris } \\
\text { adalah } \\
\text { pelajaran yang } \\
\text { menyenangka } \\
\text { n. (I think } \\
\text { English is a fun } \\
\text { subject) }\end{array}$ & - & - & $\begin{array}{l}20 \\
\%\end{array}$ & $60 \%$ & $\begin{array}{l}20 \\
\%\end{array}$ \\
\hline 2. & $\begin{array}{l}\text { Menurut saya, } \\
\text { mendengarka } \\
\text { n dan } \\
\text { menonton } \\
\text { video kata } \\
\text { adalah hal } \\
\text { yang } \\
\text { menyenangka } \\
\text { n. (In my } \\
\text { opinion, } \\
\text { listening to } \\
\text { and watching } \\
\text { videos is fun) }\end{array}$ & - & - & $\begin{array}{c}20 \\
\%\end{array}$ & $60 \%$ & $\begin{array}{l}20 \\
\%\end{array}$ \\
\hline 3. & $\begin{array}{l}\text { Menurut saya } \\
\text { jika pelajaran } \\
\text { bahasa Inggris } \\
\text { menggunakan } \\
\text { video, maka } \\
\text { pelajarannya } \\
\text { akan } \\
\text { menyenangka } \\
\text { n. (I think if } \\
\text { the English } \\
\text { lesson uses } \\
\text { video, then } \\
\text { the lesson will } \\
\text { be fun). }\end{array}$ & - & - & $\begin{array}{c}20 \\
\%\end{array}$ & $20 \%$ & $\begin{array}{l}60 \\
\%\end{array}$ \\
\hline
\end{tabular}

Table 1.1 reported that from the participants' experience, all almost students agree YouTube videos made them happy in learning English because it provides make them more focus and understand the material. The participant preferred Youtube Video to the other platform because it provided a clearer and more detailed explanation.

From the interview that experiences question is about, "Apa pendapat anda tentang belajar bahasa Inggris dengan mendengarkan dan menonton video?" (What do you think about learning English by listening and watching videos?). Syifa's opinion as to the first participant who said that "bisa lebih paham, karena suka ada beberapa orang yang menggunakan bahasa inggris dalam video, jadi saya bisa pelan-pelan belajar bahasa inggris lewat video tersebut (I can understand better because some people like to use English in the video, so I can slowly learn English through the video)". Similarly, Salman's opinion as to the second participant, "menurut saya, belajar bahasa inggris lewat video itu menarik (in my opinion, learning English through videos is interesting)". It is also in line with Tri's opinion as to the third participant from the interview that, "saya setuju dengan adanya pembelajaran bahasa inggris melalui video karena mudah dimengerti (I agree with learning English through video because it is easy to understand)". Also the opinion of Aisiah as to the fourth participant who stated that "menurut saya lebih menyenangkan dan seru menonton video dibandingkan dengan tulisan (I think it is more fun and exciting to watch videos than writing)". The 1 participant who did not agree was Rayhan who stated, "menurut saya agak sulit dipahami, karena tidak melihat secara langsung (I think it's a bit difficult to understand because I don't see it directly)" That is the opinion of the participants who agree and disagree when English material is presented on YouTube videos from the researcher's question, " $A p a$ 
Jurnal Edumaspul,5 (2), Year 2021 - 807

(Tanti Tiara, Yousef Bani Ahmad, Abdul Kodir Al-Baekani)

pendapat anda tentang belajar bahasa Inggris dengan mendengarkan dan menonton video?" (What do you think about learning English by listening and watching videos?).

\section{b. Participant's Comprehension}

Table 1. Participant's Comprehension

\begin{tabular}{|c|c|c|c|c|c|c|}
\hline No & $\begin{array}{l}\text { Pernyataan } \\
\text { (Statements) }\end{array}$ & $\begin{array}{l}\text { STS } \\
\text { (SD } \\
\text { ) }\end{array}$ & $\begin{array}{c}\text { TS } \\
\text { (D } \\
\text { ) }\end{array}$ & $\begin{array}{l}B S \\
(N)\end{array}$ & $\begin{array}{c}S \\
\text { (A) }\end{array}$ & $\begin{array}{c}\text { ST } \\
\text { (SA } \\
\text { ) }\end{array}$ \\
\hline 13. & $\begin{array}{l}\text { Menurut saya } \\
\text { video } \\
\text { pelajaran } \\
\text { bahasa } \\
\text { Inggris akan } \\
\text { membuat } \\
\text { saya lebih } \\
\text { mampu } \\
\text { menangkap } \\
\text { materi } \\
\text { dengan } \\
\text { mudah. } \\
\text { (I think video } \\
\text { lessons in } \\
\text { English will } \\
\text { make me } \\
\text { more able to } \\
\text { catch the } \\
\text { material } \\
\text { easily) }\end{array}$ & - & - & $\begin{array}{l}20 \\
\%\end{array}$ & $\begin{array}{l}40 \\
\%\end{array}$ & $\begin{array}{l}40 \\
\%\end{array}$ \\
\hline 15. & $\begin{array}{l}\text { Menurut saya } \\
\text { apabila } \\
\text { materi dalam } \\
\text { video bahasa } \\
\text { Inggris } \\
\text { diulang } \\
\text { kembali, } \\
\text { maka saya } \\
\text { akan lebih } \\
\text { paham. } \\
\text { (I think if the } \\
\text { material in } \\
\text { the English } \\
\text { video is } \\
\text { repeated, } \\
\text { then I will } \\
\text { understand } \\
\text { better) }\end{array}$ & - & - & $\begin{array}{l}20 \\
\%\end{array}$ & $\begin{array}{l}60 \\
\%\end{array}$ & $\begin{array}{l}20 \\
\%\end{array}$ \\
\hline
\end{tabular}

\begin{tabular}{|c|c|c|c|c|c|c|}
\hline 18. & $\begin{array}{l}\text { Menurut saya } \\
\text { melihat } \\
\text { lembar } \\
\text { materi atau } \\
\text { tugas selama } \\
\text { menonton } \\
\text { video } \\
\text { berbahasa } \\
\text { Inggris akan } \\
\text { mempermud } \\
\text { ah } \\
\text { pemahaman } \\
\text { saya belajar } \\
\text { bahasa } \\
\text { Inggris. } \\
\text { (I think that } \\
\text { looking at the } \\
\text { material or } \\
\text { assignment } \\
\text { sheets while } \\
\text { watching } \\
\text { English videos } \\
\text { will make it } \\
\text { easier for me } \\
\text { to } \\
\text { understand } \\
\text { learning } \\
\text { English.) }\end{array}$ & & & $\begin{array}{l}40 \\
\%\end{array}$ & $\begin{array}{l}20 \\
\%\end{array}$ & $\begin{array}{l}40 \\
\%\end{array}$ \\
\hline 20. & $\begin{array}{l}\text { Menurut } \\
\text { saya, bagian } \\
\text { dari video } \\
\text { bahasa } \\
\text { Inggris harus } \\
\text { dapat di stop } \\
\text { sebentar } \\
\text { supaya saya } \\
\text { dapat } \\
\text { memahami } \\
\text { materinya. } \\
\text { (In my } \\
\text { opinion, part } \\
\text { of the English } \\
\text { video should } \\
\text { be paused for } \\
\text { a while so } \\
\text { that I can } \\
\text { understand } \\
\text { the material.) }\end{array}$ & - & - & $\begin{array}{l}20 \\
\%\end{array}$ & $\begin{array}{c}20 \\
\%\end{array}$ & $\begin{array}{l}60 \\
\%\end{array}$ \\
\hline
\end{tabular}

Table 1.2 revealed that when the language in YouTube videos is not overly complicated, the learner can better understand the 
subject. It suggests that a Youtube video can assist a learner in comprehending the material by employing English language. This finding confirmed the theory from Balcikanli (2011), who stated that YouTube offers many opportunities to learn a second language because students can watch and listen to various types of spoken material (formal, informal), genres (songs, debates, talk shows, film clips).

The next point who researcher findings in comprehension question from "Apakah belajar dengan menggunakan video membuat Anda fokus dan memahami materi bahasa Inggris?" (Does learning using videos make you focus and understand English material?) is participants claimed to be more focused and understanding when learning English using videos. This statement supported by Syifa's perception, Syifa "iya karena saya video yang saya tonton sudah cukup membuat saya fokus dan memahami materi bahasa inggris" (yes, because the videos I watch are enough to make me focus and understand the English material). The second participant named Salman also has the same opinion, "iya, karena dengan menggunakan video saya bisa lebih paham dan fokus daripada membaca di file" (yes, because by using videos I can understand and focus more than reading on files). Tri as the third participant also thought, "iya, saya akan lebih fokus dan memahami materi lewat video" (yes, I will be more focused and understand the material through videos). As well as Aisiah's opinion, "iya, karena materi dalam video lebih lengkap dan mudah dipahami" (yes, because the material in the video is more complete and easy to understand). And Raihan who argues, "kalau dibandingkan dengan tulisan lebih fokus dengan menonton video" (when compared to writing, he is more focused on watching videos).

\section{c. Participant's Difficulty}

8. Menurut saya jika tidak ada pemakaian bahasa Indonesia di dalam video berbahasa Inggris, maka saya akan kesulitan memahami maksud video tersebut.

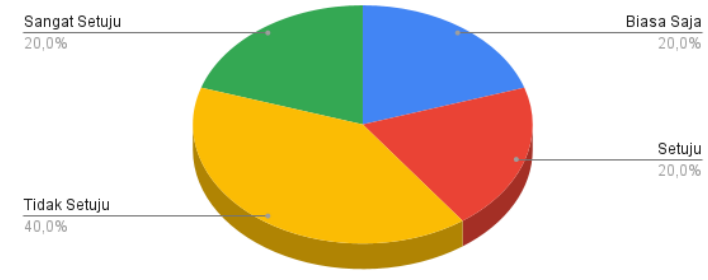

Figure 1. Participant's Difficulty

Figure 2. shows participants' perceptions of difficulties when they do not use Indonesian when learning English using YouTube videos. This is shown in the statements "Menurut saya jika tidak ada pemakaian bahasa Indonesia di dalam video berbahasa Inggris, maka saya akan kesulitan memahami maksud video tersebut (In my opinion, if there is no use of Indonesian in the English video, then it will be difficult for me to understand the meaning of the video)," and responses 3 out of 5 the participants who agree that when they watch videos without Indonesian subtitles, they are less able to understand the content of the material presented. And 2 other partisipants disagree with the statement, because they feel that even if they don't use Indonesian subtitles, they can still understand what the material is in the video.

And the participants' difficulty question is "Apa saja kesulitan yang Anda temukan saat guru Anda memberikan materi bahasa inggris melalui video? (What are the difficulties you find when your teacher gives English material through video?)." From the results of interviews, researchers can conclude that 4 out of 5 participants think there are difficulties they find as long as they are given English material through YouTube videos by their teachers, such as teachers who do not have time to explain the material that has been given through videos and then immediately gives assignments, vocabulary 
which is still foreign to them so that it is difficult to understand, there is no opportunity for students to ask questions about material they do not understand, and about the explanation of material in the video which is too fast or too long but the explanation is difficult for students to understand. This was conveyed by Syifa "kesulitan saya saat guru memberikan materi lewat video adalah guru belum sempat memberikan penjelasan terhadap materi yang akan dibahas dan selalu tiba-tiba memberikan video berikut dengan tugasnya (My difficulty when the teacher gives material via video is that the teacher has not had time to explain the material to be discussed and always suddenly gives the following video with the task)." The next participant also thought that there were difficulties when studying the videos that had been given "kalau untuk kesulitannya, terkadang ada kosa kata yang masih asing dan belum saya temui (for the difficulty, sometimes there is vocabulary that is still unfamiliar and I have not met)," said Tri. Another opinion about her difficulties regarding learning to use videos is from Aisiah, "kesulitannya, kalau ada materi yang saya kurang mengerti, saya tidak bisa menanyakannya secara langsung kepada guru saya (the difficulty is, if there is the material that I don't understand, I can't ask my teacher directly)." And Rayhan as a participant also expressed his opinion about his difficulty in learning English using video "kesulitannya, kurang bisa dipahami karena materi yang dijelaskan terlalu sedikit. Terkadang ada juga yang panjang penjelasannya tapi sulit untuk dimengerti (the difficulty is that it cannot be understood because the material explained is too little. Sometimes there are also long explanations but difficult to understand)." And of the 5 participants who thought they had difficulties when learning English material through videos, there was 1 participant who had a different opinion from the other four participants, Salman said "menurut saya, tidak ada kesulitan dalam belajar bahasa inggris melalui video (In my opinion, there is no difficulty in learning English through videos)".

\section{Discussion}

In addition, reseacrher can be concluded by the finding questionnaers result, that almost all students feel fine and enjoy during the pandemic the teacher provides English material through YouTube videos that are shared in Telegram class groups. This statements supported by Asyar (2011:42) in his book states: "the benefit of using media in learning activities and processes is to increase students' understanding of a material, so that students have many choices according to their characteristics or needs. Not only the material is interesting, but the enthusiasm and interest in student learning also increases so that they can focus more on learning and the effectiveness of teaching and learning activities is increasingAnd for students who find it difficult to understand the material because the video does not have Indonesian subtitles, they can overcome these difficulties by recording sentences they do not understand and then they look for the meaning of the sentence, so that they can understand the content of the material in the video.

Futhermore, the researcher got from the interviews that had been conducted on the use of YouTube-Based interactive media to giving English material was that 4 out of 5 eighth grade students at SMPN 2 Telukjambe Timur Karawang liked and were happy with the way teachers delivered material through YouTube videos during this pandemic because they become the focus of learning and the material becomes easy to understand. That statement supported by Wigati (2018) explain the purpose of learning YouTube as a learning media is to create 
Jurnal Edumaspul, 5 (2), Year 2021 - 810

(Tanti Tiara, Yousef Bani Ahmad, Abdul Kodir Al-Baekani)

conditions and an atmosphere of learning that interesting, fun and interactive.

\section{CONCLUSION}

Based on the results of research and discussion on the use of Youtube-Based interactive learning media in giving English subject material in SMP Negeri 2 Telukjambe Timur eight grade students, the researcher determined that, based on the participants' previous experiences, learning to use YouTube videos makes them happy and allows them to enjoy the material offered by their teacher. And practically all students enjoy learning through YouTube. And, in conclusion to finding in comprehension the participants, the features of subtitles and visual display in Youtube videos provide a more clear explanation, and the participants are more focused and understand the content in a fun style that does not bore the students. Additionally, it was indicated in the results of the difficulty of the participants that not all participants found it difficult when provided material via video. Some people, though, find it difficult. This is because students have not mastered some uncommon sentences, thus they are less able to understand the content of the material offered when they view videos without Indonesian subtitles. As a result, students are less capable of understanding the details of the video's material.

\section{Daftar Pustaka}

Abdulloh, A., Fahmi, M. Z., \& Siswanto, I. (2019). Penggunaan Media Sosial (Youtube) Sebagai Media Inovatif Dalam Pembelajaran Di Madrasah Gresik. Jurnal ABDI: Media Pengabdian Kepada Masyarakat, 5(1), 33-37.

Almurashi, W. A. (2016). The Effective Use of YouTube Videos for Teaching English Language in Classrooms as Supplementary Material at Taibah University In Alula. International
Journal of English Language and Linguistics Research, 4(3), 32-47.

Andika. 2014. Berani Sukses Karena Andal Memakai Youtube. Yogyakarta :Mediakom Herwibowo, Yudhi. 2008.

Youtube. Yogyakarta : Bentang Pustaka.

Anggraini, Diah Retno, Pemanfaatan Youtube Sebagai Media Pembelajaran Dalam Meningkatkan Kreatifitas Guru Bahasa Inggris Mts Al-Insan, jurnal pendidikan, http://papers.uikabogor.ac.id/download.php?id $=147$

Balcikanli, C. (2011). Long live, YouTube: L2 stories about YouTube in language learning.

Retrieved January 20, 2015, from, http://moodle.bracu.ac.bd/mod/resour ce/view.php?id $=8$

Creswell, J. W., \& Creswell, J. D. (2017). Research design: Qualitative, quantitative, and mixed methods approaches. Sage publications.

Decree of the Minister of Health of the Republic of Indonesia Number HK.01.07 / MENKES / 104/2020 concerning the Determination of Novel Corona Virus Infection (2019nCoV Infection) as a Disease that can lead to Outbreaks and Efforts to Control Them.

Faizah, Umi. Mohammad Fakhrudin dan Bagiya. 2018. Implementasi Media Pembelajaran Youtube Retorika Dakwah Pendidikan Berbasis Pendekatan Ilmiah di Universitas Muhammadiyah Purworejo.

Hanson, G., \& Haridakis, P. (2008). YouTube users watching and sharing the news: A uses and gratifications approach. Journal of Electronic Publishing, 11(3).

Haryadi. 2019. PEMANFAATAN YOUTUBE SEBAGAI MEDIA AJAR DALAM MENINGKATKAN MINAT DAN MOTIVASI BELAJAR. Jurnal Komunikasi Hasil Pemikiran dan Penelitian. P-ISSN: 2461-0836; EISSN: 2580-538X. Vol. 5; No. 1. 
Jurnal Edumaspul,5 (2), Year 2021 - 811

https://www.klikmania.net/10-jenis-videoyang-banyak-menghasilkanuangdiYouTube, Diakses pada 22 Desember 2019.

https://arenalte.com/berita/industri/3-faktamurid-lebih-senang-belajar-dikelasdigital-samsung/, di akses pada 12 Januari 2020

https://kupang.tribunnews.com/2019/03/18/m edia-pembelajaran-videoscribemeningkatkan-prestasi-belajarsiswa, di akses pada 12 Januari 2020

https://tekno.kompas.com/read/2018/09/26/1 3120047/siapa-yang-lebihpercayayoutube-ketimbang-bukuternyata-bukan-milenial. di akses pada 12 Januari 2020

Mandibergh (2012). Relationship Intensity of Accessing Social Media to Learning Behavior Productive Subjects in Class XI Students of Catering Services at SMK N 3 Klaten.

Mayer, R. (2001). Cognitive principles of multimedia learning: The role of modality and contiguity. Journal of Education Psychology.

Napikul, S., Cedar, P., \& Roongrattanakool, D. (2018). The Effects of Film Subtitles on English Listening Comprehension and Vocabulary. Faculty of Humanities, Naresuan University, Tha Pho District, Amphoe Mueang Phitsanulok, Thailand.

Nofrika, I. (2019). EFL Students' Voices: The Role of Youtube in Developing English Competencies. Madrasah Tsanawiyah Negeri 3 Kutai Kartanegara

Sirait, Dahlia Harahap, Yulia Sari (2021).

The Use of Youtube-Based

Interactive Learning Media in Learning English in the New Normal Era. European Journal of English Language Teaching ISSN: 2501-7136 ISSN-L: 2501-7136

Sirait, D., \& Handayani, A. T. (2020). Analisis Pemecahan Masalah Kemampuan Menulis Mahasiswa Melalui Media Pembelajaran Berbasis
Video. Jurnal Penelitian Pendidikan Bahasa Dan Sastra, 5(1), 43-49.

Watkins, J., \& Wilkins, M. (2011). Using YouTube in the EFL classroom. Language Education in Asia.

Wigati, S., Rahmawati, D. S., \& Widodo, S. A. (2018). Pengembangan youtube pembelajaran berbasis $\mathrm{Ki}$ Hadjar Dewantara untuk materi integral di SMA. In Prosiding Seminar Nasional Pendidikan Matematika Etnomatnesia (pp. 810-813)

Wilson, A. (2015). YouTube in the Classroom. Ontario Institute for Studies in Education of the University of Toronto. 